\title{
WOMEN, CRIME AND THE SECULAR COURT IN EIGHTEENTH CENTURY CLUJ ${ }^{3}$
}

\author{
Andrea Fehér \\ Babes-Bolyai University, \\ Cluj-Napoca, Romania \\ feher_andrea@yahoo.com
}

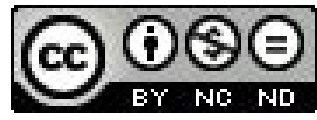

\begin{abstract}
The purpose of this presentation is to address the issue of female criminality in early modern Cluj, and to analyze women's position before the law. Our investigation is based on the records of the secular Court from the town Cluj, where we have identified more than 250 cases of women accused of fornication, adultery, witchcraft, infanticide, theft and drunkenness, poisoning, swearing and slander. There were a significant number of female convictions during the century, from which most ended with light sentences, such as banishment, corporal punishments, stigmatizations with hot iron, mutilations and only occasionally death. We would like to analyze in detail the types of crime and their punishments presenting the legal background, the jurisdiction and the habitual practices of the Court. We would also like to underline the importance of the narrative strategies used in these inquisitorial trials, since our documents reveal female criminality from a male perspective, as in these times men ran the legal system, consequently the Court records, in our reading contain moral, legal and sexual elements of a male discourse on female crime.
\end{abstract}

Keywords: women history, female crime, infanticide, witchcraft, sodomy, death penalty, social history of crime

In the last decades, we have witnessed an explosion of work regarding women's history, not just on a descriptive level but on a highly theorized one as well. Unfortunately, this field of inquiry is still in its infancy in our country, not necessarily because of a narrowness of vision, which clearly exists (especially among older historians), but primarily because of the lack of sources, which prevents Transylvanian historians from writing about women's history in particular. The sources we have for early modern history came both from and refer to the elite, to privileged environments. Therefore, the few gender-related studies that we do have provide an incomplete and revised insight into the lives of wealthy females: incomplete because the sources present women primarily as

3 This work was possible due to the financial support of the Sectorial Operational Program for Human Resources Development 2007-2013, co-financed by the European Social Fund, under the project number POSDRU/159/1.5/S/140863 with the title "Competitive European researchers in the fields of socio-economics and humanities. Multiregional research net (CCPE)" 
devoted mothers and wives, revised because all of the narratives with which we are working came from the male elite. Therefore, we know little about the lives of women of modest birth. In the following, we will attempt to contribute to the literature on this issue by presenting marginalised women as they are revealed through the legal documents produced by the Court of a Transylvanian town.

The modern town of Cluj (Kolozsvár, Klausenburg), situated in the centre of Transylvania, a wealthy settlement with royal privileges, inhabited by Saxons and Hungarians, struggled with social and political instability in the midst of historical events in the beginning of the $18^{\text {th }}$ century. Over the years, the town returned slowly to its previous stability, as suggested by the fact that the number of citizens doubled from 7,000 (1711) to 13,928 (1787), when it was the third largest town in Transylvania (Csetri, 2001, pp. 9,14). It is particularly important to note the Protestant character of the town, since the citizens of Cluj were ardent followers of Unitarianism, a situation that changed partially due to the pressure of the Protestant princes of Transylvania and then the Counter-Reformation.

The secular Court Protocols of the town of Cluj are the source of our survey. Written partially in Latin and Hungarian, many have unfortunately been lost, including numerous decisions and deliberations from the first decade of the eighteenth century. Unlike those of earlier centuries, the trial documents from this period contain only the deliberations: neither the testimonies of the witnesses nor of the accused were included; therefore, we only occasionally have access to the words of the actors. Nonetheless, we do have access to the minds of the judges and primarily the scribes, who, despite the fact that they did not use lengthy narratives, demonstrated a significant interest in expressing not just the local perception of what was socially accepted as female behaviour but their personal convictions as well. At the same time, the records occasionally offer an interesting intrusion into the minds of the accused. Therefore, in addition to analysing the legal background of female crime, we would also like to examine some of the related rhetorical elements.

Our analysis is based on 264 cases related to female crime and criminality. The numbers suggest that most of the women were accused of fornication, adultery, witchcraft, infanticide, theft, drunkenness, poisoning, swearing and slander. In the following, we would like to present the major and the most frequent female crimes, such as sexual misbehaviour, infanticide and witchcraft.

Most of the crimes associated with women had a sexual dimension. Moral offences, such as fornication and adultery, were the most frequent female crimes, and were present with the same intensity throughout the century. Vigilant bourgeoisie both discovered and denounced the majority of fornication and adultery cases. No matter how personal and natural the experience of sex was, in these Protocols, it was turned into a public issue, a matter of state and society. Intimate gestures, looks and touches all fell under the supervision of others and reckless intentions were rapidly transformed into accusations. The image of women who refused to comply with the rules for social coexistence was especially negative and rooted in the belief that women tend to fall repeatedly into sin. Our analysis shows that, although they were flogged and expelled from the town 
every time, a significant percentage of the women continued to reappear in Court over a period of several years. One such case, sensational in its time, was that of Judith Csitra (1759, C.P. II/46:236, II/46: 362), a lame woman, who was barely able to move. She appeared repeatedly before the judges, accused of fornication. At her first appearance, the magistrates were clearly influenced by her physical condition and expelled her from Cluj on a cart; however, after numerous scandals, they gave her the 'well deserved' corporal punishment, 'a serious flog'. The judges were just as stunned when they sentenced Sára Csiszár (1730-1731, C.P.II/33: 131, II/35: 10-11, II/35:28-29) three times in four months and by Mária Szilágyi Szécsi (1731, C.P. II/34: 26), who continued her dissolute life in prison as well. These women are described as 'restless, seeking to satisfy their carnal pleasures' and apparently 'no punishment can stop them', as they are 'whores by nature'.

Fornication and debauchery cases were frequently judged in collective trials. In many cases, we found two, three and sometimes even four women cited before the Court and all receiving identical punishments. Curiously, in these cases, men are always invisible; we do not know their names, their intentions or their marital status; sometimes we know their occupation. The most commonly used descriptions in the Protocols for cases of sexual immorality are that defendants 'steal, drink and party with strangers' and 'drink, spend time in suspicious places and whoring with German soldiers'. This fact could be easily explained by the presence of the German garrison on the outskirts of Cluj. Since it was generally accepted that ethnic minorities, strangers (in this case soldiers) were considered a source of violence, depravity and deviance (Nye, 2004, p. 17; Antalóczy, 2000, p. 102), this would explain why almost all fornication cases mentioned the German soldiers. We must also note that a significant percentage of the women accused and condemned for fornication were outsiders as well. However, the Court did not have legal authority over the military, as it had over these women. Despite the fact that there were some laws concerning deviant female behaviour, during this century, there was a general lack of legal reasoning regarding debauchery and fornication; most of the offences were solved by customary law and justified with rulings such 'as she deserved' and sometimes with 'as the law said'.

The situation appears similar with the adultery cases. There is a common perception in the subject's literature that 'cases of adultery were prosecuted only in those instances where the woman involved was married' (Kingsley Kent, 2004, p. 94). However, since some elements suggest a different approach regarding male and female adultery, this statement is not entirely valid for Cluj. In Transylvania, the Approbatae Constitutiones (1653: Pars. III. Tit. 47, Art. 21), which called for the death penalty in cases of adultery, regulated marital and unmarried behaviour. Curiously, while cited frequently for male adultery, mention of the law was almost entirely absent for female adultery. We also find it intriguing that, in the first half of the century, there were only a small number of male adultery cases and they always named the women involved, regardless of whether they were married or not. Although more numerous, the female adultery cases contain no male names, with the exception if the partner was also committing adultery. Since other Town Courts acted in the same way (Antalóczy, 2000, p. 102), this seems to 
have been the general tendency. In Cluj, the change occurred towards the end of the century, when males became more visible, both as adulterous partners as well as in convictions.

Even if there was a law that required a specific punishment for married and unmarried persons, this law was first interpreted and not just administered. After analysing a large number of fornication and adultery cases, we concluded that the interpretation of the same crime-type varied from case-to-case and depended on numerous factors, such as age, crime frequency, criminal record, physical condition and even political conjunctures. Women involved in such cases for the first time typically had a relatively light punishment, such as whipping, flogging and/or expulsion. However, in cases regarding a repeated sin, or associated offences (such as debauchery, robbery or scolding), they were mutilated or marked with a hot iron. Nonetheless, in certain situations, physical punishment, and even the death penalty, could be avoided, since participants in the trial behaved in such a manner as to win the jury's sympathy (Rabin, 2005, p. 167). Even if it was extremely difficult for these women to have the sympathy of the Court, some factors could help the adulterous person to reduce their offense from a capital to a non-capital offense. A brief outline of frequently evoked excuses is presented below to provide a better understanding of the legal reasoning behind these offences.

Age was one of the most evoked excuses. It was commonly accepted that young persons, especially if they had an older partner, tend to fall into sin. In these cases, the families of the defendant had a tremendous influence on negotiating mitigation; a simple act of forgiveness was enough for salvation. Likewise, it was not unusual to see children begging for the life of their adulterous parents as well. While many escaped the death penalty because they were young and 'driven by others', just as many elderly, who fell into the temptation of the flesh, were spared. We can sometimes hear the desperate call of older wives who hunted their husband, because 'this will not rest until he made his way with a virgin'. In addition to age, a longer detention could also influence the verdict; for example, in 1775 , the young wife of an honourable guild member was released without major penal consequences after a long solitary confinement, because judges hoped that the time spent in the town's prison had awakened her sense of responsibility (C.P. II:53/121). There was also, of course, the issue of love. Contrary to what we would like to think about early-modern marital behaviour, the Court Records prove that it was generally accepted that, although against any natural or moral rule, marital love could end earlier than it should. We hear the desperate voices of women who 'wanted neither their husband's soul, nor their body' and excuses like 'I would not lay my eyes on strangers if God would give me a better husband'. The women in question were not given a better husband but a harsh flogging and expulsion instead (1725, C.P. II:29/162-163); at least, they were not put to death. In addition to the fact that magistrates accepted that love could end, they were also aware that living alone, especially after the beginning of sexual life, could be extremely difficult. Therefore, many adulterous women and men who had lived several years without their spouses were given light sentences. Many escaped because their legal partner was also adulterous; in some cases, using sleep and alcohol as 
excuses made some impression as well. We only have two records that testify that mental excuses were used; both refer to males.

In some cases, married persons made dramatic decisions, such as to end the life of their legal spouse. We have three women as examples: two poisoned their husbands (1753, C.P. II: 44/206; 1777, C.P. II: 54/91-96) and one encouraged her lover to kill him (1767, C.P. II:49/125-126). The first two women, Erzsébeth Pál and Erzsébeth Székely, did everything they could to kill their legal partner: poisoning first with arsenic, then with nitric acid, trying to push their drunken husbands from the bridge into the river, and paying others, such as servants or even the surgeon, to kill them - hoping that this would make a definite phlebotomy. Their initial sentence was death, but since one man survived and the other died from pharyngitis, the wives escaped relatively easy. It is obvious that the women from these trials were not exactly passive victims of a male-dominated society; moreover, they were not as uninformed as we tend to think of females from lower social classes as being. Székely confessed to her neighbour, 'I do not mind if they catch me, because I know that they will put me into the tower, and if they do so, then I will pay my 66 forints, and before that I will go to the priest and confess, I would probably fast, so I won't have any problems'. She almost got it right: she was whipped (66 lashes in two rows) and expelled (C.P. II: 54/93). The most severe punishment was given to the adulterous Anna Tordai, first because she had a lover and second because, after a fight between the two males, 'she contrary to her marital oaths cried over her lover' and 'wished her spouse's death'. The magistrates sentenced her to death: she made an appeal, but the initial sentence was not changed. She made another appeal and her case finally ended up on the Supreme Royal Court; however, we do not know how it concluded.

From the cases mentioned above, it was clearly a common practice to frighten defendants with death and then give them a less severe punishment; most women indeed appealed their sentences. From more than 100 sex-related cases, only two women were executed. Undoubtedly, these women were sentenced to death because the judges wanted to make them examples to the citizens of Cluj. Nonetheless, these two cases were extreme and very different in nature from the others; at the time, both women were considered a moral scourge. In Sára Katona's 1704 adultery case (Fasc. II/425), the Court wanted to make her an example for the citizens of Cluj and 'for anyone who dared to violate the town's social and moral rules'. She was condemned to die because she was a drunk, depraved, swore and cursed, exposed her naked body publicly and confessed that her child was not from her legal spouse. According to the scribe, 'she would deserve death for any of these' [further enumerated sins]. The second trial, from 1712 (C.P. II/ 26: 64, 68$69)$, which started initially as a simple adultery process, turned into a fascinating sodomite-case. András/Erzsébet Ungvári, who dressed in men's clothes, lived in marriage with other women and was sentenced for sodomy, found her end in flames (Fehér, 2012).

It is extremely important to note that the first decade of the century was characterized by military tension, social insecurity and muddled political conjunctures. The behaviour of both of the above mentioned women was seen as 
an offence against secular and religious order; consequently, it is possible that, as we will see in the witchcraft cases, the severe punishments, especially for the first case, served a social purpose.

Since accusations of infanticide usually targeted women, as indicated by archival sources as well as the literature (Kilday, 2013, p. 24), infanticide is considered a specifically female crime. In the town's Protocols, we found 11 records concerning infanticide and child murder (Fehér, 2014). Seven of the accused women were unmarried and three had children from adulterous relationships, suggesting that illegitimacy had a strong relationship with infanticide. It is noteworthy that all of the women accused of infanticide were convicted either of adultery, fornication or debauchery. This was regardless of whether they received the death penalty or not, which indicates that infanticide and illegitimacy could also be related to deviancy. These women clearly had negative images and they were associated with sin and immorality.

The Protocols from Cluj mention three eighteenth century cases of proven infanticide that ended with the death sentence. The women were all unmarried and one was a foreigner (Ilona Kosztin, 1728; C.P. II/32:23-24) who came into the city on the night she delivered her child.

As mentioned previously, in cases of adultery and fornication, the role of the curious neighbours and bourgeois in disclosing female crime (but not just female crime) was significant. Driven by curiosity, and presumably suspicion, the first case was denounced by neighbours and other females who were looking for Erzsébet Szatmári (1723; C.P. II/29:22), who was found immediately after delivery, with 'blood-covered hands' and a strangled newborn child. In Kosztin's case, the host noticed traces of blood in the yard and, on following them, found a child's corpse hidden in dung. Some citizens found the third child in a clay pit, but the mother was found after a long investigation (Mária Stefán, 1750; C.P. II/44:113-114). Since it was extremely important to offer a detailed description of the physical condition of the newborn, the above mentioned neighbours, citizens and curious females sometimes contributed significantly to the understanding of the crime. They described the body they found, including the child's neck, belly and tongue, which offered precious information regarding the cause of death. The scribe typically used lengthy narratives to elucidate the circumstances in which these women committed murder. Based probably on very colourful stories narrated by the witnesses, the judges tried to recreate their own story to understand the cases better. If there were no mitigating circumstances, they gave the death sentence, but these were not necessarily unanimous. In the case of Kosztin, there is no mention of execution, while both Stefán and Szatmári were initially sentenced to be buried alive in a pit of thorns (as was the custom before) but had their sentences commuted and changed to decapitation. None of the sentences mentioned a specific law. However, one law did call for live burial in a pit of thorns. We consider that, in cases of infanticide, the judges from Cluj applied the first body of German criminal law, Constitutio Criminalis Carolina, which stipulated that women who gave birth in secret without asking for the help of midwives or other females and then claimed that the child had died during delivery should be convicted of infanticide 
and executed by burial in thorns (art. 131) (Tóth, 1997, pp. 32-33; Deáky, Krász, 2005, p. 106). The end of the century brought a different approach to this crime and women started to be perceived as victims, not criminals. In 1769, Empress Maria Theresa attempted to prevent infanticide by banning the death penalty in cases committed by mothers. Joseph II added a note to these regulations, in 1781, forbidding humiliating pregnant women in public as 'the reason of this tragedy [infanticide] is to be found precisely in shame and fear of humiliation' (Hajdu, 1985, pp. 18-19).

Statistically, the number of cases of infanticide is identical to that of the witchcraft trials. These two female crimes - infanticide and witchcraft - appear to have been closely related, as they generated identical fears at the collective level (Hoffer, \& Hull, 1981, p. 56) and often had a common actor, namely, the midwife. In the studied materials from 11 witchcraft cases (1711-1765), the majority involve women who practiced the art of midwifery at some point in their life or who knew how to prepare various medicines and delivered a sort of non-professional medical care. In Cluj, witchcraft cases typically related to elderly women who dallied with medicine and prepared herbal remedies or acted as midwives. Nonetheless, it is also equally true that most of these women did not have an unblemished reputation. The majority are described as having 'unclean mouth[es]' and being 'lewd sluts' who 'displayed publicly their private parts'; moreover, despite their quite advanced age, they 'forced men to sin with them'. Ultimately, these figures of speech suggest that it was not necessarily the women's magical skills but their conduct that mattered. In half of our cases, the women were only suspected of paranormal powers; only some of the cases contain specific allegations regarding unclean or occult practices, such as invisibility, astral projection or the power to cause or cure diseases (especially by spitting). The original reason for the allegations was a pragmatic one: magical items were used simply to ensure the success of the trial.

We would like to use the case of Kata Kádár as an example to present this female related crime. As mentioned previously, the Protocols that contained the inquisitions are lost. There is only one complete trial document, preserved partly in the Hungarian National Library and partly in the National Archives in Cluj, and that is the trial of Kata Kádár, from 1733-1734. In addition to the trial narratives of this case, there is also a note in the Account Books of the town that elucidates the cost of a witch trial and what preparations were needed to perform an execution by burning. From these documents, we learn that, in Kádár's case, there were two interrogations and that women and men were equally involved as witnesses. The questions asked were meant to elucidate both the nature of Kádár's power and the circumstances in which it was used. Although many said that Kádár possessed the power to cause and cure diseases, to turn into a wasp during the night and to take away a cow's milk, she never described her power in her confession and no explanation was provided for the accusation. Many of the interrogated had their magical experiences in dreams; they felt pain during sleep, saw the witch in their dream and after they woke up, they had physical signs of their astral experience, such as swallows or patches. Since many conflicts between the witch and the 
damaged persons took place during the night, the questions that the interrogators asked in these trials were meant to elucidate whether the experience was just a dream or if it actually happened in reality as well. Most of the so-called visitations occurred at night, usually after a real conflict that occurred during the daytime and was witnessed by many. The majority of these women who were accused of witchcraft lived at the edge of society, in poverty, as was the case with Kádár. She begged for food and drink and when she was not successful, she started to issue threats. Since magical skills were a definite source of social power, many times women such as Kádár contributed to their own negative image. Even if we know that Hungarian and Transylvanian legislation condemned deeply all of the actions that involved unnatural elements, there was a deep-rooted conviction in the existence of not just evil but beneficial magic as well. Moreover, that kind of magic was related to healing. Many confessed that they had asked for Kádár's help in their injuries, fractures and swellings, and that they got angry after they were not cured. Any time that an unexpected tragedy occurred, she was the first to be both contacted and blamed. Her skills were required in numerous circumstances and matters in which she had little or no control. She became aware of that fact, as she said in her confession, 'I see, I must die because of your words'. After not receiving what they wanted, citizens frightened Kádár profoundly, threatening her with such things as, if she deny the help, she 'will rise with smoke to sky' and 'I'll find three carts of wood and three carts of straw and make a fire' (Kiss, Pakó, \& Tóth, 2014, pp. 340, 337, 346). As mentioned previously, women were not passive, powerless and ignorant subjects of the trial. In her apologia, Kádár cited the law from the Tripartitum (Part. II., Tit. 28) and asked for the erasure of the depositions, since almost all of the interrogated had 'bad feelings for her' (Kiss, Pakó, \& Tóth, 2014, p. 350). Nevertheless, because they understood that she had 'made a pact with the devil', became his instrument and harmed the innocents, the judges were not impressed. She was condemned to die in flames and to be tortured before death: pain that she could escape, if she cured all of the persons that she had 'maimed' (C.P. II/36:3-4).

The Town's Accounts mentioned all of the expenses for this execution: from the money given for the services of the carpenter to the executioner. The most striking expense was the money given for courage, which suggests that, presumably, even if the executioner had great experience with death, he was still unfamiliar with the sight of a burning body. Some money was paid for beheading, so it is also possible that Kádár's pain was eased and she was killed before she was put on the pile.

As the other executions suggest, in the aforementioned trial, there was a long journey from the trial to the pile. Investigations of witchcraft, as well of infanticide, were extremely long. All of the women executed for witchcraft were incarcerated for several months: Erzsébet Ötves (September 1728-January 1729), Kádár (September 1733-February 1734) and Judit Péntek (October 1741-May 1743). Since some of the accused were not citizens of Cluj, investigations were necessary. Our research shows that, especially in complicated cases, the Court of Cluj communicated with other secular Courts in Transylvania to collect more evidence and learn about the criminal records of the prisoners. These efforts 
sometimes delayed deliberations, as these types of crime were extremely difficult to prove.

It is important to note that Cluj was a Protestant town and the first Transylvanian decrees on witchcraft date from the Lutheran Synod (1577), which provided death for all people who 'walk with magic' (both white and maleficent). Although contradictory, these laws do not denote an actual belief in paranormal powers but rather scepticism, since Protestant ministers did not accept the existence of occult forces and had an anti-diabolical and anti-demonological perception. Completely denying the possibility of a pact or an act of sodomy consummated with the devil, they regarded these descriptions as illusions of minds possessed by melancholy. However, Protestant leaders opposed magic, particularly magical practices related to healing and especially during epidemics (Kristóf, 2014, pp. 29-31). This could explain why, during the epidemics, in Cluj in 1741, four women (Kata Pál, Zsófia Katona, Suska Bíró and Judit Péntek) were led before the judicial forum. However, only one was condemned to death (Péntek); the rest were expelled.

As in infanticide cases, the Protocols from Cluj did not mention any specific law concerning witchcraft, the only certainty is that cases of witchcraft were resolved by fire. Although the first sentence was always burning alive, judges frequently changed their sentences to decapitation, which was followed by burning the dead body. The change in the legal perception of this crime occurred, as it did in cases of infanticide, due to the reforms of Maria Theresa and Joseph II. Influenced by great personalities, such as the physicians Gerard van Swieten and Joseph von Sonnenfels, and the Italian jurist Cesare Beccaria, from 1750, the Habsburg rulers issued decrees against torture and witchcraft (Deáky, \& Krász, 2005, pp. 107-109). To avoid the 'excesses of zeal from the rural Courts', they also demanded the submission of all witchcraft cases to the Court in Vienna, moves which aroused widespread discontent among local populations (Tóth, 2014, pp. 69-71).

We are aware of the fact that certain aspects of the past, such as gender and women's experiences, especially for females belonging to lower classes, can be extremely difficult to describe. The sources are silent and when they do speak, as in our case, they are from a male perspective; therefore, when it comes to the profile of female criminals, a series of factors must be deconstructed, especially on the narrative level. From these records, we came to understand that women were neither passive victims of male seduction nor were they subjugated by a male dominated legal system. Females, just as males, knew how to play their social roles as well as how to make their sin look less significant to impress the judges, who in turn did everything that they could to understand every case in the best way possible.

\section{REFERENCES}

Antalóczy I. (2000). Erkölcsi búncselekmények Debrecenben a XVIII. sz. közepén. Debreceni Szemle, 1, 101-119.

Csetri E. (2001). Kolozsvár népessége a középkortól a jelenkorig. In: T. Dáné, Á. Egyed, G. Sipos, R. Wolf (Eds.), Kolozsvár 1000 éve. A 2000. Október 13 -14-én rendezett konferencia elóadásai (pp. 9-28). Kolozsvár: Erdélyi Múzeum-Egyesület. 
C.P. Romanian National Archives Cluj County Branch, Cluj-Napoca, The Town Archive of Cluj, Court Protocols.

Deáky Z., Krász L. (2005). Minden dolgok kezdete. A szülés kultúrtörténete Magyarországon (XVI-XX. század). Budapest: Osiris.

Fehér A, (2012). Crossing Gender Boundaries. The Trial of Andrew Ungvári (1712). Studia Universitatis "Babeş-Bolyai", Historia, 57, nr. 2, 1-20.

Fehér A, (2014). Investigating Infanticide in $18^{\text {th }}$-Century Cluj. Studia Universitatis "Babeş-Bolyai", Historia, 59, nr. 2, 52-65.

Hajdu L. (1985). Büntettés büntetés Magyarországon a XVIII. század utolsóharmadában. Budapest: Magvető.

Hoffer, P., Hull (1981). Murdering mothers: Infanticide in England and New England 1558-1803. New York: New York University Press.

Kilday, A. (2013). A History of Infanticide in Britain c. 1600 to the Present. Palgrave - Macmillan.

Kingsley Kent, S. (2004). Gender Rules: Law and Politics. In: T. Meade, M. Wiesner-Hanks (Eds.), A Companion to Gender History (pp. 86-109). Blackwell.

Kiss A., Pakó L., Tóth P. (Eds.) (2014). Kolozsvári boszorkányperek, 1564-1743. Budapest: Balassi.

Kristóf Sz. I. (2014). Boszorkányüldözés a kora újkori Magyarországon. In G. Klaniczay, É. Pócs (Eds.), Boszorkányok, varázslók és démonok Közép-Kelet-Európában (pp. 17-62). Budapest: Balassi.

Nye, R. (2004). Sexuality. In: T. Meade, M. Wiesner-Hanks (Eds.), A Companion to Gender History (pp. 11-25). Blackwell.

Rabin, D. (2005). Identity, Crime and Legal Responsibility in Eighteenth-Century England. Palgrave - Macmillan.

Tóth G. P. (1997). A lázadók teste és az árulók büntetése. A pápai vallon zsoldosok kivégzése és a megtorlás hóhértechnológiájának kultúrtörténeti emlékei. Pápai Múzeumi Értesitoő. 7, 19-66.

Tóth G. P. (2014). A mágia dekriminalizációja és a babonaellenes küzdelem Magyarországon és Erdélyben, 1740-1848. In G. Klaniczay, É. Pócs (Eds.), Boszorkányok, varázslók és démonok Közép-Kelet-Európában (pp. 63-83). Budapest: Balassi. 